\title{
Prevalence, risk factors and bacterial causes of bo- vine mastitis in southern Ethiopia
}

Rahmeto Abebe ${ }^{1^{*}}$, Mesele Abera ${ }^{1}$, Yifat Denbarga ${ }^{1}$, Mishamo Suleyman ${ }^{1}$, Amene Fekadu ${ }^{1}$, Fufa Abunna ${ }^{2}$, Adugna Abebe ${ }^{3}$, Demisie Wale ${ }^{4}$,Erdachew Kassa ${ }^{5}$, Beyene Tune ${ }^{6}$

${ }^{1}$ Hawassa University, Faculty of Veterinary Medicine P. O. Box 05, Hawassa, Ethiopia

${ }^{2}$ Addis Ababa University, College of Veterinary Medicine, P.O. Box 34, Bishoftu, Ethiopia

${ }^{3}$ South West Shewa Livestock and Fishery Development Office, Oromia, Ethiopia

${ }^{4}$ West Gojam Livestock and Fishery Development office, Amhara, Ethiopia

${ }^{5}$ Hawassa city Administration Agricultural Department

${ }^{6}$ Sidama Zone Livestock and Fishery Development office, SNNPRS, Ethiopia

*Corresponding author: email rahmetoabe @gmail.com; Tel +251 911541384

\begin{abstract}
Mastitis is one of the most economically important diseases in dairy farms worldwide. It is particularly important in Ethiopia where no routine prevention and control practices are in place. This cross-sectional study was carried out between October 2017 and June 2018 to estimate the prevalence of mastitis, identify the associated risk factors and isolate bacterial causes in dairy farms located in southern Ethiopia using standard microbiological methods and questionnaire survey. A total of 686 lactating cows which were found in 122 selected dairy farms were investigated by physical examination and California mastitis test. The overall cow-level prevalence of mastitis was $54.2 \%$ (95\% CI: $50.5-57.9 \%)$. Based on the study site, the prevalence was $55.7 \%$ in Hawassa, $54.3 \%$ in Arsi Negele, 52.6\% each in Wondo Genet and Wolayta Soddo towns with no significant $(p>0.05)$ difference among the sites. The majority of mastitis cases were subclinical $(48.1 \%)$ while the clinical mastitis was only $6.1 \%$. Of the 122 herds tested, 109 (89.3\%; 95\% CI: $82.1-93.9 \%)$ had at least a cow positive for mastitis. The study showed that high parity number $(\mathrm{OR}=1.6 ; p=0.015)$, flat $(\mathrm{OR}=4.5 ; p<0.001)$ and round $(\mathrm{OR}=2 ; p$ $<0.001)$ teat end shape, history of mastitis in preceding lactation $(\mathrm{OR}=3.3 ; p$ $<0.001$ ), and slightly ( $\mathrm{OR}=3.5 ; p<0.001)$, moderately ( $\mathrm{OR}=4.9 ; p<0.001$ ), and very dirty $(\mathrm{OR}=9.2 ; p<0.001)$ udder and legs were the major risk factors which are significantly associated with higher prevalence of mastitis. Based on the available media and reagents, the major bacteria isolated from subclinical
\end{abstract}


mastitic milk samples were Staphylococcus spp. (57.3\%), Streptococcus spp. (18.6\%), E. coli (17.3\%) and Bacillus spp. (7.5\%) in order of their abundance. The present study revealed a high prevalence of mastitis, particularly the subclinical one, and the associated risk factors. Enhancing the awareness of dairy farmers, regular screening of cows for subclinical mastitis, proper treatment of the clinical cases, improving the hygienic condition of the cows, and culling of chronically infected cows are critically important to prevent and control bovine mastitis.

Keywords: Mastitis, Prevalence, Risk factors, Southern Ethiopia

\section{Introduction}

Mastitis is an inflammation of the parenchyma of mammary glands characterized by physical, chemical and usually, bacteriological changes in milk and pathological changes in glandular tissues. The most important changes in the milk include discoloration, the presence of milk clots and large number of leucocytes in milk (Radostits et al., 2007). It is a multi-etiological and complex disease resulting from the interaction of three major factors: infectious agents, host resistance, and environmental factors (Gera and Guha, 2011).

Mastitis is a global problem adversely affecting animal health, quality of milk and the economics of milk production (Sharma and Sindhu, 2007). It is the most widespread infectious disease in dairy cattle (Tiwari et al., 2000; Elango et al., 2010; Sharma et al., 2012). Mastitis can occur either in clinical or subclinical forms. The clinical mastitis is characterized by changes in the udder and milk that are directly observable, whereas the subclinical mastitis is characterized by an increase in somatic cell count in the milk and absence of visible clinical signs (Kivaria et al., 2004).

Mastitis is of a particular concern for farmers in developing countries like Ethiopia. In Ethiopia, there are several bovine mastitis studies showing spatial variations in prevalence and risk factors. According to most recent studies, the prevalence of mastitis ranges from 39.5 - 62.6\% (Belayneh et al., 2013; Tolosa et al., 2013; Abebe et al., 2016; Birhanu et al., 2017). Since Ethiopia is a country with diverse agro-ecological conditions, it is obvious that mastitis prevalence and associated risk factors can vary from region to region. Thus, it is important to investigate the causes and risk factors of the disease in parts 
of southern Ethiopia to formulate mastitis control program adapted to the specific local situation. The present study aims to estimate the prevalence of bovine mastitis, associated risk factors, and identify the major bacterial causes of mastitis in dairy farms in southern Ethiopia.

\section{Materials and Methods}

\section{Study area}

The study was conducted in small scale dairy farms located in Hawassa, Wendo Genet, Wolayita Sodo and Arsi Negelle towns which are high potential areas for dairy production in southern Ethiopia. The first three towns are found in Southern Nations, Nationalities and People's Regional State (SNNPRS) whereas Arsi Negelle is in Oromiya Regional State. Hawassa is located $275 \mathrm{Kms}$ south of Addis Ababa at $7^{\circ} 3^{\prime} \mathrm{N}$ latitude and $38^{\circ} 48^{\prime} \mathrm{E}$ longitude. It is situated at an elevation of 1708 meters above sea level. Hawassa receives an average annual rain fall of $900 \mathrm{~mm}$ and has mean annual temperature of $20^{\circ} \mathrm{C}$. Wendo Genet is located at $30 \mathrm{Kms}$ west of Hawassa. It is situated at about 1723 meters above sea level, $7^{\circ} 5^{\prime} \mathrm{N}$ latitude and $38^{\circ} 37^{\prime} \mathrm{E}$ longitude. The average annual rainfall of the town is $1372 \mathrm{~mm}$ while mean annual temperature is $19^{\circ} \mathrm{C}$. Wolayta Sodo is situated at $6^{\circ} 54^{\prime} \mathrm{N}$ latitude and $37^{\circ} 45^{\prime} \mathrm{E}$ longitude, and has an elevation between 1600 and 2100 meters above sea level. The average annual rainfall of the town ranges from $450 \mathrm{~mm}$ to $1446 \mathrm{~mm}$ while the mean annual maximum and minimum temperature of the town are $26.6{ }^{\circ} \mathrm{C}$ and 11.4 ${ }^{0} \mathrm{C}$, respectively. Arsi Negelle is found in the West Arsi zone of the Oromia regional state at a distance of $225 \mathrm{Kms}$ from Addis Ababa. The town is situated at about 2043 meters above sea level at $7^{\circ} 21^{\prime} \mathrm{N}$ latitude and $38^{\circ} 42^{\prime} \mathrm{E}$ longitude. The average annual temperature of the area varies from 10 to $25^{\circ} \mathrm{C}$ while rainfall varies between 500 and $1000 \mathrm{~mm}$.

\section{Study population}

The study population covers lactating dairy cows raised under semi-intensive or intensive management system. In intensive farms, cattle were kept indoors all the time and provided with roughages and concentrates. The semi-intensive farms are characterized by outdoor grazing at day time and provision of supplementary feed in the morning and evening before milking. House construction design in the study areas also varied from farm to farm. In some of the farms, the wall was made of bricks while in others it was built from wood and 
mud. The floors of houses were constructed from concrete, wood or soil compact with or without beddings. In most of the houses, drainage system was not sufficient enough to remove slurry. Although it was difficult to get the actual figure, the approximate number of dairy farms found in the towns were $107 \mathrm{in}$ Hawassa (Libiyos, 2018, unpublished data), 35 in Arsi Negelle (Teherku, 2018, unpublished data), 33 in Wolayta Sodo (Dema, 2018, unpublished data) and 63 in Wendo Genet (Wendo Genet Wereda Livestock and Fisheries Development Office, 2018, unpublished data). The size of the herds in the study towns ranged from 2 to 131 cattle with average herd size of 7 cattle per herd.

\section{Study design and sample size}

The study employed a cross-sectional study design. The required sample size was determined using the recommended formula (Thrusfield, 2005) with 95\% confidence interval, $5 \%$ absolute precision, 0.15 between cluster variance $(\mathrm{Vc})$ and $62.6 \%$ expected cow level prevalence (Abebe et al., 2016). Based on the given formula, the number of farms calculated was 122 and with predicted average number of five cows per farm, the minimum sample size was determined as 610 cows. The sample size was allocated proportionally to each of the study areas based on their dairy cattle population size. Accordingly, a sample size of 305, 152, 135, and 94 dairy cows was allocated for Hawassa, Wolayta Sodo, Wendo Genet, and Arsi Negelle towns, respectively. The dairy farms were selected randomly but all lactating cows found in the selected farms were included in the study.

\section{Clinical examination}

A thorough physical examination of the udder and teats was conducted on all lactating cows for evidence of clinical mastitis. Clinical findings such as secretions, abnormalities on size and shape of the udder, its consistency and temperature were assessed by visual inspection and palpation. Then, the cows negative for clinical mastitis were subjected to California Mastitis Test (CMT) for detection of subclinical mastitis. CMT was carried out according to the procedure described by Quinn et al (2002). In brief, a squirt of milk, about $2 \mathrm{ml}$ from each quarter, was placed in each of the four shallow cups in the CMT paddle. An equal amount of CMT reagent was added to each cup. A gentle circular motion was applied to the mixtures in a horizontal plane for 15 seconds. The CMT result was scored as negative (0 and trace), 1 (weak positive), 2 (distinct positive) and 3 (strong positive) based on gel formation. 


\section{Bacteriological analysis}

A total of 307 milk samples were collected from sub clinically affected (CMT positive) cows aseptically based on the procedure described in NMC (1999). The teats were wiped thoroughly with $70 \%$ ethyl alcohol and approximately $10 \mathrm{ml}$ of milk were collected into a sterile bottle after discarding the first 3 milking stream. After collection, samples were transported in an icebox to Microbiology Laboratory, Faculty of Veterinary Medicine of Hawassa University. In the laboratory, samples were cultured immediately or stored at $+4^{\circ} \mathrm{C}$ for a maximum of 24 hours until inoculated on a standard bacteriological media (NMC, 1999).

A loopful of the milk samples was streaked on blood agar base (Himedia, India) which was enriched with 5\% sheep blood, and MacConkey agar (Himedia, India). Bacterial growths were identified and recorded after incubation for 24 to 48 hours at $37^{\circ} \mathrm{C}$ aerobically. Identification of bacterial isolates was done based on colony morphological features and hemolytic reactions (primary cultures), gram staining reactions and biochemical tests (INVIC, Catalase and Coagulase tests) on pure cultures (Quinn et al., 2002).

\section{Questionnaire survey}

During farm visits, a semi-structured questionnaire was used to collect data about herd and cow level variables thought to influence the prevalence of mastitis. The questionnaire was administered to farm owners/attendants through a face-to-face interview by four final year undergraduate veterinary students (one in each site) who were conducting research for graduation. Some of the variables were recorded by direct observation of the milking and husbandry practices. The data collectors had received training before initiation of the research to ensure that recording was consistent. The herd level variables recorded were herd size, management (intensive or semi-intensive), floor type (concrete, wood or soil), bedding (yes or no), pre or post milking teat dipping, udder washing practices (whole udder or teats only), housing (stall barn or group barn), use of towel for drying (yes or no), whether mastitic cows milked last or not, culling chronically infected cows, and dry cow therapy. Cow level data included age, parity, stage of lactation, udder position (normal or pendulous), teat end shape (pointed, round or flat), cow dirtiness (clean, slightly dirty, moderately dirty or very dirty), and previous history of mastitis. 


\section{Data analysis}

Data collected through questionnaire survey and CMT were entered into Microsoft Excel spread sheet and then exported to Stata 14.2 statistical software (StataCorp, 4905 Lakeway Drive, College Station, Texas) for analysis. The prevalence of cow-level mastitis was calculated by dividing the number of mastitis-positive cows (clinical and subclinical) by the total number of animals tested while herd-level prevalence was determined by dividing positive herds by total number of herds. A herd was considered as positive if at least one cow tested positive for clinical or subclinical mastitis. Possible risk factors for mastitis were selected using univariable mixed effect logistic regression analysis with farm ID as a random effect to account for clustering at herd level. All variables having $p$-value $<0.25$ in the initial univariable analysis were further checked for co-linearity using Kruskal gamma statistics before multivariable analysis, and those variables whose gamma value ranged between -0.6 and +0.6 were considered in a multivariable logistic regression model. During multivariable mixed effect logistic regression analysis, all non-significant variables were removed sequentially by backward elimination where the model with the lowest Akaike Information Criterion (AIC) value was chosen as the best model. At every step during model development, the confounding effect of herd size was assessed by checking for changes in parameter estimates, and changes $>25 \%$ were considered to indicate confounding (Dohoo et al., 2009). To compare differences in cow level prevalence in the four sampling towns, logistic regression with sampling town as a categorical variable and a farm as a random effect was performed. In all analyses, confidence levels were calculated at $95 \%$ and a $p$ value $<0.05$ was used for statistical significance level.

\section{Results}

The overall prevalence of mastitis at cow level was $54.2 \%$ (95\% CI: $50.5-57.9 \%$ ). The majority of mastitis cases in the cows tested was subclinical (48.1\%) while the prevalence of clinical mastitis was only $6.1 \%$. No significant $(p>0.05)$ difference was noted in the prevalence of mastitis across the four sampling towns (Table 1). Among the 122 herds examined in the study, 109 (89.3\%; 95\% CI: $82.1-93.9 \%)$ of them had at least a cow positive for mastitis. All the herds examined in Wolayta Sodo, 95.8\% in Arsi Negele, 85.4\% in Hawassa and 83.3\% in Wendo Genet were positive for mastitis. The prevalence varied between $0 \%$ and $100 \%$ within a herd at an average herd prevalence of $52 \%$ (Table 2). 
Table 1. Prevalence of cow-level clinical and subclinical mastitis in dairy cows in the southern Ethiopia

\begin{tabular}{lccccc}
\hline $\begin{array}{l}\text { Sampling } \\
\text { town }\end{array}$ & $\begin{array}{l}\text { No } \\
\text { examined }\end{array}$ & $\begin{array}{l}\text { Clinical } \\
\text { mastitis }\end{array}$ & $\begin{array}{l}\text { Subclinical } \\
\text { mastitis }\end{array}$ & Overall & 95\% CI \\
\cline { 3 - 5 } & & Positive (\%) & Positive (\%) & $\begin{array}{l}\text { Positive } \\
\text { (\%) }\end{array}$ & \\
\hline Wendo Genet & 135 & $17(12.6)$ & $54(40)$ & $71(52.6)$ & $44.1-60.1$ \\
Wolayita Sodo & 152 & $4(2.6)$ & $76(50)$ & $80(52.6)$ & $44.7-60.5$ \\
Arsi Negele & 94 & $10(10.6)$ & $41(43.6)$ & $51(54.3)$ & $44.1-64.1$ \\
Hawassa & 305 & $11(3.6)$ & $159(52.1)$ & $170(55.7)$ & $50.1-61.2$ \\
Total & $\mathbf{6 8 6}$ & $42(6.1)$ & $330(48.1)$ & $\mathbf{3 7 2} \mathbf{( 5 4 . 2 )}$ & $\mathbf{5 0 . 5}-\mathbf{5 7 . 9}$ \\
\hline
\end{tabular}

Table 2. Herd-level prevalence of mastitis in dairy farms in the southern Ethiopia

\begin{tabular}{lcccc}
\hline Sampling town & Herds tested & Positive herds & $\begin{array}{l}\text { Prevalence } \\
(\%)\end{array}$ & 95\% CI \\
\hline Wendo Genet & 36 & 30 & 83.3 & $66.5-93.0$ \\
Wolayita Sodo & 21 & 21 & 100 & $80.8-100$ \\
Arsi Negele & 24 & 23 & 95.8 & $76.8-99.8$ \\
Hawassa & 41 & 35 & 85.4 & $70.2-93.9$ \\
Overall & 122 & 109 & 89.3 & $82.1-93.9$ \\
\hline
\end{tabular}

Out of the 2744 quarters examined, 111 (4.1\%) were found blind and nonfunctional. The frequency of blind teats was slightly higher on the hind quarters than front quarters, and the overall quarter level prevalence of mastitis was $29.4 \%$ (Table 3).

Table 3. Proportion of blind quarters and prevalence of mastitis at quarter level in dairy cows in southern Ethiopia

\begin{tabular}{lccccc}
\hline Quarter & $\begin{array}{l}\text { No } \\
\text { quarters }\end{array}$ & $\begin{array}{l}\text { Blind quarters, } \\
\text { n (\%) }\end{array}$ & $\begin{array}{l}\text { No quarters } \\
\text { tested }\end{array}$ & No positive & $\begin{array}{l}\text { Prevalence } \\
\text { (\%) }\end{array}$ \\
\hline RH & $\mathbf{6 8 6}$ & $\mathbf{3 5 ( 5 . 1 )}$ & $\mathbf{6 5 1}$ & $\mathbf{1 8 4}$ & $\mathbf{2 8 . 3}$ \\
LH & 686 & $24(3.5)$ & 662 & 203 & 30.7 \\
RF & 686 & $29(4.2)$ & 657 & 195 & 29.7 \\
LF & 686 & $23(3.4)$ & 663 & 191 & 28.8 \\
Total & $\mathbf{2 , 7 4 4}$ & $\mathbf{1 1 1 ( 4 . 1 )}$ & $\mathbf{2 , 6 3 3}$ & $\mathbf{7 7 3}$ & $\mathbf{2 9 . 4}$ \\
\hline
\end{tabular}

RF = Right front; LF = Left front; RH = Right hind; LH = Left hind; 
In the present study, various possible risk factors at cow and farm levels were evaluated for their effect on mastitis prevalence. Univariable mixed effect logistic regression was performed on age, parity, lactation stage, udder position, teat end shape, history of mastitis, cow dirtiness, herd size, milking mastitic cow, management (intensive/semi-intensive), floor type (concrete, wood or soil), bedding (yes or no), washing udder before milking (whole udder or teats only), housing (stall barn or group barn), use of towel for drying (no, separate or common) and sampling town (Table 4). Out of 16 possible risk factors analyzed, parity, lactation stage, udder position, teat end shape, history of mastitis, cow dirtiness, milking mastitic cow and herd size had $\mathrm{p}<0.25$ and thus selected for multivariable analysis. Co-linearity was checked between variables before multivariable analyses. Accordingly, age was dropped from further analysis due to co-linearity with parity (gamma $=1$ ) and history of mastitis in preceding lactation (gamma $=0.64$ ). Parity was retained in the analysis due to its higher biological importance than age in relation to mastitis. The best fit model included parity, teat end shape, cow dirtiness, and history of mastitis as significant factors associated with prevalence of mastitis in cows. The final model showed that higher parity $(\mathrm{OR}=1.6 ; \mathrm{p}=0.018)$, history of mastitis in preceding lactation $(\mathrm{OR}=3.4 ; \mathrm{p}<0.001)$, round $(\mathrm{OR}=2.2 ; \mathrm{p}<0.001)$ and flat teat ends $(\mathrm{OR}=4.6 ; \mathrm{p}<0.001)$, and slightly dirty $(\mathrm{OR}=2.9 ; \mathrm{p}<0.001)$, moderately dirty $(\mathrm{OR}=3.2 ; \mathrm{p}<0.001)$ and very dirty $(\mathrm{OR}=8 ; \mathrm{p}=0.001)$ udder and legs were significant factors associated with cow-level mastitis prevalence (Table 5). Herd size showed no association with mastitis prevalence $(p=0.109)$. However, the role of herd size as a confounder was investigated by fitting models for mastitis prevalence with and without herd size included. None of the coefficients for the other variables changed substantially when herd size was excluded, so we concluded that any confounding effect of herd size was minimal. 
Table 4. Results of univariable mixed effect logistic regression analysis of potential animal and herd level risk factors with mastitis prevalence

\begin{tabular}{|c|c|c|c|c|c|}
\hline Risk factors & Category & $\begin{array}{l}\text { No cows } \\
\text { examined }\end{array}$ & $\begin{array}{l}\text { No cows positive } \\
(\%)\end{array}$ & $\begin{array}{l}\text { Crude OR (95\% } \\
\text { CI) }\end{array}$ & p-value \\
\hline \multirow[t]{2}{*}{ Age } & $\leq 8 \mathrm{yrs}$ & 576 & $289(50.2)$ & 1 & \\
\hline & $>8 \mathrm{yrs}$ & 110 & $83(75.5)$ & $3.1(1.9-4.9)$ & $<0.001$ \\
\hline \multirow[t]{2}{*}{ Parity } & Primiparous & 177 & $69(40)$ & 1 & \\
\hline & Multiparous & 509 & 303 (59.5) & $2.4(1.6-3.4)$ & $<0.001$ \\
\hline \multirow[t]{3}{*}{ Lactation } & $\leq 4$ month & 209 & $102(48.8)$ & 1 & \\
\hline & $>4$ to 8 month & 335 & $185(55.2)$ & $1.3(0.9-1.9)$ & 0.127 \\
\hline & $>8$ month & 142 & $85(59.9)$ & $1.6(1.0-2.5)$ & 0.038 \\
\hline \multirow[t]{2}{*}{ Udder position } & Normal & 569 & $287(50.4)$ & 1 & \\
\hline & Pendulous & 117 & $85(72.7)$ & $2.7(1.7-4.2)$ & $<0.001$ \\
\hline \multirow[t]{3}{*}{ Teat end shape } & Pointed & 288 & $117(40.6)$ & 1 & \\
\hline & Round & 331 & $199(60.1)$ & $2.5(1.7-3.6)$ & $<0.001$ \\
\hline & Flat & 67 & $56(83.6)$ & $8.1(3.9-16.7)$ & $<0.001$ \\
\hline \multirow[t]{2}{*}{ History of mastitis } & No & 458 & $196(42.6)$ & 1 & \\
\hline & Yes & 228 & $176(77.2)$ & $4.7(3.2-6.9)$ & $<0.001$ \\
\hline \multirow[t]{4}{*}{ Cow dirtiness } & Clean & 229 & $81(35.4)$ & 1 & \\
\hline & Slightly dirty & 285 & $176(61.8)$ & $3.5(2.3-5.4)$ & $<0.001$ \\
\hline & Moderately dirty & 149 & $97(65.1)$ & $4.9(2.8-8.7)$ & $<0.001$ \\
\hline & Very dirty & 23 & $18(78.3)$ & $9.2(2.9-29.2)$ & $<0.001$ \\
\hline \multirow[t]{2}{*}{ Herd size } & $\leq 10$ & 162 & $78(48.2)$ & 1 & \\
\hline & $>10$ & 524 & $294(56.1)$ & $1.4(0.9-2.0)$ & 0.109 \\
\hline \multirow[t]{2}{*}{ Management } & Semi-intensive & 105 & $58(55.2)$ & 1 & \\
\hline & Intensive & 581 & $314(54)$ & $0.97(0.6-1.7)$ & 0.920 \\
\hline \multirow[t]{3}{*}{ Floor type } & Wood & 17 & $6(35.3)$ & 1 & \\
\hline & Earth/soil & 37 & $19(51.4)$ & $0.5(0.1-1.95)$ & 0.336 \\
\hline & Concrete & 632 & $347(54.9)$ & $1.1(0.5-2.4)$ & 0.750 \\
\hline \multirow[t]{2}{*}{ Housing } & Stall barn & 214 & $117(54.7)$ & 1 & \\
\hline & Group barn & 472 & $255(54)$ & $0.95(0.6-1.4)$ & 0.803 \\
\hline \multirow[t]{2}{*}{ Bedding } & Yes & 136 & $72(52.9)$ & 1 & \\
\hline & No & 550 & $300(54.6)$ & $1.0(0.7-1.6)$ & 0.927 \\
\hline \multirow{2}{*}{$\begin{array}{l}\text { Udder washing before } \\
\text { milking }\end{array}$} & Teats only & 46 & $22(47.8)$ & 1 & \\
\hline & Whole udder & 635 & $348(54.8)$ & $0.76(0.4-1.5)$ & 0.430 \\
\hline \multirow[t]{3}{*}{ Towel use } & No & 152 & $75(49.3)$ & 1 & \\
\hline & Common & 142 & $76(53.5)$ & $1.3(0.8-2.0)$ & 0.244 \\
\hline & Separate & 392 & $221(56.4)$ & $1.2(0.7-1.97)$ & 0.515 \\
\hline \multirow{2}{*}{$\begin{array}{l}\text { Milking mastitis cow } \\
\text { last }\end{array}$} & No & 270 & $139(51.5)$ & 1 & \\
\hline & Yes & 416 & $233(56)$ & $0.8(0.6-1.2)$ & 0.268 \\
\hline
\end{tabular}

Ethiop. Vet. J., 2020, 24 (1), 52-68 
Table 5. Best-fit multivariable model for risk factors associated with cow-level mastitis prevalence using mixed effect logistic regression modelling with farm as random effect

\begin{tabular}{|c|c|c|c|c|}
\hline Risk factors & Category & $\begin{array}{l}\text { Crude OR (95\% } \\
\text { CI) }\end{array}$ & $\begin{array}{l}\text { Adjusted OR } \\
(95 \% \mathrm{CI})\end{array}$ & p-value \\
\hline \multirow[t]{2}{*}{ Parity } & Primiparous & 1 & 1 & \\
\hline & Multiparous & $2.3(1.6-3.3)$ & $1.6(1.1-2.5)$ & 0.018 \\
\hline \multirow[t]{2}{*}{ History of mastitis } & No & 1 & 1 & \\
\hline & Yes & $4.5(3.2-6.5)$ & $3.4(2.3-5.1)$ & $<0.001$ \\
\hline \multirow[t]{3}{*}{ Teat end shape } & Pointed & 1 & 1 & \\
\hline & Round & $2.2(1.6-3.0)$ & $2.2(1.5-3.2)$ & $<0.001$ \\
\hline & Flat & $7.4(3.7-14.8)$ & $4.6(2.1-9.9)$ & $<0.001$ \\
\hline \multirow[t]{4}{*}{ Cow dirtiness } & Clean & 1 & 1 & \\
\hline & Slightly dirty & $2.9(2.1-4.2)$ & $2.9(1.9-4.4)$ & $<0.001$ \\
\hline & Moderately dirty & $3.4(2.2-5.3)$ & $3.2(1.8-5.6)$ & $<0.001$ \\
\hline & Very dirty & $6.6(2.4-18.4)$ & $8.0(2.4-26.1)$ & 0.001 \\
\hline Constant & & & $0.1(0.04-0.21)$ & $<0.001$ \\
\hline
\end{tabular}

\section{Bacteria isolated}

Bacterial examination was performed on 307 milk samples collected from cows with subclinical mastitis. However, due to lack of media and other facilities, isolation was limited to only certain bacteria. Accordingly, growth of different types of bacteria was observed in 299 (97.4\%) of the samples cultured. Staphylococcus spp. were the most prevalent bacteria isolated from $57.3 \%$ of the samples cultured. Streptococcus spp., E. coli and Bacillus spp. were the other bacteria isolated in decreasing order of their prevalence (Table 6).

Table 6. Bacteria isolated from mastitic milk samples $(\mathrm{N}=307)$

\begin{tabular}{lcc}
\hline Type of bacteria & No isolates & Prevalence (\%) \\
\hline Staphylococcus spp. & 176 & 57.3 \\
Streptococcus spp. & 57 & 18.6 \\
E. coli & 53 & 17.3 \\
Bacillus spp. & 23 & 7.5 \\
\hline
\end{tabular}




\section{Discussion}

Mastitis is the most costly disease in the dairy industry worldwide. It is a complex disease that results from the interaction of many factors involving the host, agent and environment. This study investigated the prevalence, risk factors and certain bacterial causes of mastitis in four towns of southern Ethiopia known for their dairy cattle potential. Unlike most of the previous studies in the region, the information presented in this paper was derived from a large sample of 686 lactating cows found in 122 dairy farms. An overall cow-level prevalence of $54.2 \%$ and overall herd-level prevalence of $89.3 \%$ was recorded. The cow-level prevalence of this study is comparable to two previous studies in Ethiopia: $52.9 \%$ in and around Areka town (G/Michael et al., 2013) and 56.5\% in Batu and its environs (Duro and Taddele, 2011). However, it is higher than those reported in other studies that used CMT viz. 23.18\% in Doba district, West Hararghe Zone (Girma et al., 2012), 39.5\% in Adama town (Belayneh et al., 2013), 46.9\% in and around Gondar town (Alemu et al., 2013) and 40.1\% in Bishoftu town (Birhanu et al., 2017). In contrast, the present prevalence is lower than a previous report of $66.6 \%$ in Asella (Abera et al., 2013), $64.3 \%$ in Adigrat (Zenebe et al., 2014), $62.6 \%$ in Hawassa milk shed (Abebe et al., 2016) and 62\% in North-West Ethiopia (Mekonnen et al., 2017). The first metaanalysis of the prevalence of mastitis in dairy cattle in Ethiopia conducted by Getaneh and Gebremedhin (2017) indicated that the variation of mastitis prevalence between studies might be due to variation in the locality and period of study, number of animals sampled, breeds, stages of lactation, parity number, and management practices.

In the present study, higher prevalence of subclinical mastitis (SCM) (48.1\%) was observed compared to the clinical form (6.1\%), a finding that is in line with previous studies (Debele, 2010; Moges et al., 2011; Abebe et al., 2016; Kebebew and Jorga, 2016). Risk factors including higher number of parity, history of mastitis in preceding lactation, flat or round teat end shapes in cows, and cow dirtiness were the likely attributable factors to the observed high prevalence of SCM. Furthermore, absence of mastitis prevention and control practices such as post milking teat disinfection, culling chronically infected cows and dry cow therapy by most of the dairy farms are the other possible reasons. Due to lack of mastitis monitoring program and absence of visible clinical signs, cows infected with SCM remain undetected for a long time. This increases the probability of mastitis transmission from infected to uninfected cows within herds 
by the hands of milker's without the notice of the farmers (Radostits et al., 2007).

The odds of mastitis was 1.6 times higher in multiparous than primiparous cows. This finding is consistent with several previous studies (Abunna et al., 2013; Belayneh et al., 2013; Katsande et al., 2013; Zeryehun et al., 2013; Abrahmsén et al., 2014; Abebe et al., 2016). Higher prevalence of mastitis in multiparous cows might be ascribed to loosening of sphincter and patency of teat canal in older cows. Moreover, the median ligaments, which provide support to the teat, also get relaxed with age leading to hanging of udder and thus it makes more prone to mastitis (Boujenane et al., 2015; Bhat et al., 2017).

In the present study, cows with flat teat ends $(\mathrm{OR}=4.5)$ and round teat ends $(\mathrm{OR}=2)$ were more likely to have mastitis compared to those with pointed teat ends. This is perhaps because flat or round teats have wider streak canals, which can give greater chance for the entry of infectious agents, than pointed teat ends (Appleman, 1970). A similar finding was also reported by other studies like Belayneh et al. (2013), Nakov et al. (2014) and Abebe et al. (2016).

Cows with a history of mastitis in the preceding lactation were 3.3 times more likely to have mastitis than those without mastitis history. This finding is in agreement with previous studies (Houben et al., 1993; Berry and Meaney, 2005; Abebe et al., 2016). According to Elmaghraby et al. (2017), the reason for recurrent mastitis can be a persistent infection of the mammary gland by a mastitis pathogen.

The odds of finding a cow with mastitis increased as the degree of cow dirtiness increased. It was noted that the likelihood of mastitis was 8, 3.2 and 2.9 times higher in cows with very dirty, moderately dirty and slightly dirty udder and legs as compared to those with relatively clean udder and legs, respectively. It is obvious that the dirtiness of udder and hind legs is the result of poor hygiene of the cow's environment and facilities in the cows' barn. As stated by Rajabi et al. (2017), poor cow hygiene can contribute to presence of mastitis pathogens on teat ends and increasing the rate of new infections. Similar to the current finding, other researchers have also reported a significant association between mastitis prevalence and poor udder and leg hygiene (Abrahmsén et al., 2014; Iraguha et al., 2015; Abebe et al., 2016; Mureithi and Njuguna, 2016) 
Various types of contagious and environmental pathogens have been reported to cause bovine mastitis in Ethiopia. However, only four types of bacteria were isolated in the present bacteriological study due to lack of the required media and reagents. Staphylococcus spp. were the most dominant organisms isolated followed by Streptococcus spp. As stated by Mdegela et al. (2009), the dominance of Staphylococcus spp. in bovine mastitis is possibly a result of poor milking hygiene. The predominance of Staphylococcus spp. particularly S. aureus has also been reported by several bovine mastitis studies in Ethiopia (Mekibib et al., 2010; Abera et al., 2013; Belayneh et al., 2013; Zeryehun et al., 2013).

\section{Conclusions}

This study demonstrated a high prevalence of mastitis. Subclinical mastitis was the major form prevalent among the dairy farms in southern Ethiopia. Higher number of parity, history of mastitis in the preceding lactation, teat end shapes and cow dirtiness were important risk factors of bovine mastitis in the study area. The study also showed Staphylococcus spp., Streptococcus spp., E. coli and Bacillus spp. as possible causes of mastitis in the dairy farms. Therefore, raising awareness of dairy farmers, making the animals' environment clean and dry as possible, post milking teat dipping and regular screening and culling chronically infected cows are recommended as feasible interventions.

\section{Acknowledgment}

This work is part of a big thematic research project funded by the office of Vice President for Research and Technology Transfer, Hawassa University. The owners of all dairy farm participated in this study are highly acknowledged for their cooperation during the study.

\section{References}

Abebe, R., Hatiya, H., Abera, M, Megersa, B., and Asmare, K., 2016. Bovine mastitis: prevalence, risk factors and isolation of Staphylococcus aureus in dairy herds at Hawassa milk shed, South Ethiopia. BMC Vet. Res., 12(1):270 
Abera, B., Lemma, D., and Iticha, I., 2013. Study of bovine mastitis in Asella government dairy farm of Oromia Regional state, South Eastern Ethiopia. Int. J. Curr. Res. Aca. Rev. 1(2), 134-145.

Abrahmsén, M., Persson, Y., Kanyima, B.M. and Båge, R., 2014. Prevalence of subclinical mastitis in dairy farms in urban and peri-urban areas of Kampala, Uganda. Trop. Anim. Hlth. Prod., 46:99-105.

Abunna, F., Fufa, G., Megersa, B. and Regassa, A., 2013. Bovine mastitis: Prevalence, risk factors and bacterial isolation in smallholder dairy farms in Addis Ababa city, Ethiopia. Global Veterinaria. 10 (6): 647-652.

Alemu, S., Tamiru, F., Almaw, G., and Tsega, A., 2013. Study on bovine mastitis and its effect on chemical composition of milk in and around Gondar Town, Ethiopia. J. Vet. Med. Anim. Hlth., 5(8):215-221

Appleman, R. D., 1970. Quantifying the genetic effects on the anatomy of streak canal. In: Proceedings of the VI International Conference on Cattle Disease.

Duro, B. D. and Taddele, H. M., 2011. Study on Prevalence of Mastitis and its Associated Risk Factors in Lactating Dairy cows in Batu and its Environs, Ethiopia. Global Veterinaria. 7 (6):632-637.

Belayneh, R., Belihu, K. and Wubet, A., 2013. Dairy cows mastitis survey in Adama Town, Ethiopia. J. Vet. Med. Anim. Hlth., 5(10): 281-287.

Berry, D. P. and Meaney, W. J., 2005. Cow factors affecting the risk of clinical mastitis. Irish J. Agr. Food. Res. 44: 147-156

Bhat, A.M., Soodan, J.S., Singh, R., Dhobi, I.A., Hussain, T., Dar, M. Y., and Mir, M., 2017. Incidence of Bovine Clinical Mastitis in Jammu Region and Antibiogram of Isolated Pathogens. Vet. World, 10(25): 984-989.

Birhanu, M., Leta, S., Mamo, G. and Tesfaye, S., 2017. Prevalence of bovine subclinical mastitis and isolation of its major causes in Bishoftu town, Ethiopia. BMC Res. Notes, 10:767

Boujenane, I., El Aimani, J., By, K., 2015. Incidence and Occurrence Time of Clinical Mastitis in Holstein Cows. Turkish J. Vet. Ani. Sci.,39: 1-8.

Dohoo, I., Martin, W. and Stryhn, H., 2009. Veterinary Epidemiologic Research. $2^{\text {nd }}$ ed. Charlotte town: AVC Inc; p. 27-407.

Elango, A., Doraisamy, K. A., Rajarajan, G. and Kumaresan, G., 2010. Bacteriology of sub-clinical mastitis and anti-biogram of isolates recovered from cross-bred cows. Indian J. Anim. Res. 44(4): 280-284. 
Elmaghraby, M. M., El-Nahas, A. F., Fathala, M. M., Sahwan, F. M., and EL-Dien M. A. T., 2017. Incidence of Clinical Mastitis and its influence on reproductive performance of dairy cows. Alex. J. Vet. Sci. 54 (2): 84-90.

G/Michael, L., Deressa, B., Begna, F. and Mekuria, A., 2013. Study on prevalence of bovine mastitis in lactating cows and associated risk factors in and around Areka town, Southern of Ethiopia. Afr. J. Microbiol. Res., 7(43): 5051-5056

Getaneh A.M., Gebremedhin E.Z., 2017. Meta-analysis of the prevalence of mastitis and associated risk factors in dairy cattle in Ethiopia. Trop. Anim. Hlth. Prod., 49: 697-705.

Gera, S. and Guha, A. 2011. Assessment of acute phase proteins and nitric oxide as indicator of subclinical mastitis in Holstein $\times$ Haryana cattle. Indian J. Anim. Sci., 81(10): 1029-1031.

Debele, G. D., 2010. Study on prevalence of mastitis on cross breed dairy cow around Holeta areas. Global Veterinaria, 5(6): 318-323.

Girma, S., Mammo, A., Bogele, K., Sori, T., Tadesse, F. and Jibat, T., 2012. Study on prevalence of bovine mastitis and its major causative agents in West Harerghe zone, Doba district, Ethiopia. J. Vet. Med. Anim. Hlth., 4(8): 116-123

Houben, E. H. P., Dijkhuizen, A. A., van Arendonk, J. A. M. and Huirne, R. B. M., 1993. Short-term and long-term production losses and repeatability of clinical mastitis in dairy cattle. J. Dairy Sci., 76:2561-2578.

Iraguha, B., Hamudikuwanda, H. and Mushonga, B., 2015. Bovine mastitis prevalence and associated risk factors in dairy cows in Nyagatare District, Rwanda. J. S. Afr. Vet. Assoc., 86:1228.

Katsande, S., Matope, G., Ndengu, M. and Pfukenyi, D. M., 2013. Prevalence of mastitis in dairy cows from smallholder farms in Zimbabwe. Onderstepoort J. Vet. Res., 80:523.

Kebebew, G. and Jorga, E., 2016. Prevalence and risk factors of bovine mastitis in Ambo town of West Shewa Zone, Oromia, Ethiopia. Ethiop. Vet. J., 20 (1), 123-134

Kivaria, F. M., Noorhuizen, J. P. and Kapaga, A. M., 2004. Risk indicators associated with subclinical mastitis in smallholder dairy cows in Tanzania. Trop. Anim. Hlth. Prod., 36 (6): 581-592.

Mekibib, B., Furgasa, M., Abunna, F., Megersa, B. and Regassa, A., 2010. Bovine mastitis: prevalence, risk factors and major pathogens in dairy farms of Holeta town, central Ethiopia. Vet. World, 3 (9): 397-403.

Mekonnen, S. A., Koop, G., Melkie, S. T., Getahun, C. D., Hogeveen, H., and Lama, T. J. G. M., 2017. Prevalence of subclinical mastitis and associated risk factors at cow and herd level in dairy farms in North-West Ethiopia. Prev. Vet. Med., 145: 23-31.

Ethiop. Vet. J., 2020, 24 (1), 52-68 
Mdegela, R. H., Ryoba, R., Karimuribo, E.D., Phiri, E. J., Løken, T., Reksen, O., Mtengeti, E., Urio, N.A., 2009. Prevalence of clinical and subclinical mastitis and quality of milk in smallholder dairy farms in Tanzania. J. S. Afr. Vet. Assoc., 80(3): 163-168

Moges, N., Asfaw, Y. and Belihu, K., 2011. A Cross Sectional Study on the Prevalence of Sub- Clinical Mastitis and Associated Risk Factors in and around Gondar, Northern Ethiopia. Int. J. Anim. Veter. Adv., 3(6): 455-459

Mureithi, D. K. and Njuguna, M. N., 2016. Prevalence of subclinical mastitis and associated risk factors in dairy farms in urban and peri-urban areas of Thika Sub County, Kenya. Livestock Res. Rural Dev., 28 (2) :13

Nakov, D., Hristov, Andonov,S. and Trajchev, M., 2014. Udder-Related Risk Factors for Clinical Mastitis in Dairy Cows. Vet. Arhiv. 84 (2):111-127.

National Mastitis Council (NMC), 1999. Current Concept in bovine mastitis, National mastitis Council $3^{\text {rd }}$, 1840 Wilson Blvd, Arlington, VA 22201. pp: 397-432.

Quinn, P. J., Markey, B. K., Carter, E. M., Donnelly, W. J. and Leonard, F. C., 2002. Veterinary Microbiology and Microbial Disease. Blackwell Science Ltd, Blackwell Publishing Company pp: 465-474.

Radostits, O. M., Gay, C. C., Hinchcliff, K. W. and Constable, P. D., 2007. Veterinary Medicine: A text book of the disease of cattle, horses, sheep, pigs and goats. $10^{\text {th }}$ ed. London: Elsevier Ltd.

Rajabi, I., Taghavi Razavizadeh, A., Azizzadeh, M. and Khoramian, B., 2017. The investigation on the relationship between dairy cow hygiene scores and intramammary infections. Iranian J. Vet. Sci. Tech., 9 (1): 12-16

Sharma, A. and Sindhu, N., 2007. Occurrence of clinical and sub-clinical mastitis in buffaloes in the State of Haryana (India). Italian J. Anim. Sci., 6 (Suppl. 2): 965-967.

Sharma, N., Rho, G. J., Hong, Y.H., Kang, T.Y., Lee, H. K., Hur, T.Y. and Jeong, D. K., 2012. Bovine mastitis: an Asian perspective. Asian J. Anim. Vet. Adv., 7: 454-476.

Thrusfield, M., 2005. Veterinary Epidemiology. $3^{\text {rd }}$ ed. Oxford: Blackwell science Ltd; pp. 183-189.

Tiwari, A., Sisodia, R. S., Sharma, R. K., Misraulia, K. S. and Garg, U. K., 2000. Incidence of sub-clinical mastitis in cows of Malwa Region of Madhya Pradesh. Indian J. Dairy Sci., 53(4): 328-331.

Tolosa, T., Verbeke, J., Piepers, S., Supré, K., and De Vliegher, S., 2013. Risk factors associated with subclinical mastitis as detected by California Mastitis Test in smallholder dairy farms in Jimma, Ethiopia using multilevel modelling. Prev. Vet. Med., 112: 68-75. 
Zenebe, N., Habtamu, T., and Endale, B., 2014. Study on bovine mastitis and associated risk factors in Adigrat, Northern Ethiopia. Afr. J. Microbiol. Res., 7 (48), 54005417.

Zeryehun, T., Aya, T. and Bayecha, R., 2013. Study on prevalence, bacterial pathogens and associated risk factors of bovine mastitis in small holder dairy farms in and around Addis Ababa, Ethiopia. J. Anim. Plant Sci. 23 (1): 50-55. 